\title{
Two Cases with Kawasaki Diseases and Adenoviral Infection: An Etiology or Association?
}

\section{Tuba Giray, MD ${ }^{1}$, Suat Biçer, $M D^{1^{*}}$, Ahmet Saç ${ }^{2}$, Yiğit Moğol ${ }^{2}$, Öznur Küçük ${ }^{1}$, Defne Çöl' ${ }^{1}$, Zerrin Yalvaç and Yeşim Gürol, $M D^{3}$}

${ }^{1}$ Faculty of Medicine, Department of Child Health and Pediatrics, Yeditepe University, Turkey

${ }^{2}$ Faculty of Medicine, Yeditepe University, Turkey

${ }^{3}$ Faculty of Medicine, Department of Medical Microbiology and Virology, Yeditepe University, Turkey

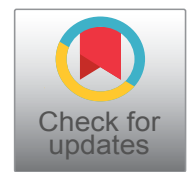

*Corresponding author: Suat Biçer, Faculty of Medicine, Department of Child Health and Pediatrics, Yeditepe University, Devlet Yolu Ankara Cad. No: 102-104-34752, Ataşehir-istanbul, Turkey, Tel: +90-216-5784910, Fax: +90-216-5784959

\begin{abstract}
Although etiology of Kawasaki disease has not been precisely determined, it has been speculated that there was an association with a variety of bacterial and viral agents because of the seasonality of this disease. Some viruses including human adenovirus have been isolated from patients with Kawasaki Disease. Adenoviral infection may mimic Kawasaki disease clinically but it may also be detected in patients with Kawasaki disease. We have presented two patients with Kawasaki disease who infected with human adenovirus in this case report.
\end{abstract}

\section{Keywords}

Adenovirus, Child, Kawasaki disease

\section{Introduction}

Kawasaki Disease (KD), which is also known as "mucocutaneous lymph node syndrome", was first defined in 1967 in Japan [1]. It is diagnosed by clinical symptoms according to American Heart Association criteria [2,3]. This disease is characterized by a suddenly onset systemic inflammatory response. Coronary artery changes including coronary vasculitis are the most important complications in KD, and cardiac findings are present in $25 \%$ of the cases $[3,4]$. It is the most commonly encountered rheumatological heart disease among children in developed countries [5]. It is known that, with early diagnosis, coronary artery changes may be reversible. In our country there is not any clear data about incidence. The incidence differences between ethnical groups lead us to think, it can be caused by genetical factor differences like chemokines and tumor necrosis factor (TNF) receptors, HLA haplotypes. It is shown that in genetically susceptible children, viral and bacterial agents trigger disease onset $[3,6]$. In our 2 cases, which are diagnosed with KD by physical examination and early echocardiographic findings, human adenovirus are established as responsible agents, and these cases are presented to literature because there is no exact etiological factor defined in KD.

\section{Case 1}

A 4-years-old male child was brought to pediatrics clinic with symptoms of fever that began 6 days ago, redness in eyes, mouth and lips, and weakness. There was not special in his background and family history. The patient has been taking antibiotherapy (amoxicillin/ clavulanate) for 6 days. In the physical examination, his general condition was exhausted, and he looked pale. The physical examinations findings were fever $\left(39.5^{\circ} \mathrm{C}\right)$, hyperemic and hypertrophic tonsils, strawberry tongue, and dryness and redness in oral mucosa and lips. There were bilateral cervical and submandibular lymphadenopathies, which were $1 \times 1 \mathrm{~cm}$ in size, painful and mobile. Bilateral nonpurulent conjunctivitis was present in his eyes. In the cardiovascular system examination it was seen that his heart rate was $140 / \mathrm{min}$ and there was $2 / 6$ systolic sufl in mitral foci. There were macu-

Citation: Giray T, Biçer S, Saç A, Moğol Y, Küçük Ö, et al. (2019) Two Cases with Kawasaki Diseases and Adenoviral Infection: An Etiology or Association?. Int J Virol AIDS 6:054. doi.org/10.23937/2469$567 X / 1510054$

Accepted: May 25, 2019: Published: May 27, 2019

Copyright: (C) 2019 Giray T, et al. This is an open-access article distributed under the terms of the Creative Commons Attribution License, which permits unrestricted use, distribution, and reproduction in any medium, provided the original author and source are credited. 
lopapular lesions on his extremity surfaces and on the trunk. There was no pathological sign in the abdomen and respiratory system examination. Peripheral blood leukocyte count was 5500/mm³ ${ }^{3}$, hemoglobin: $11 \mathrm{gr} / \mathrm{dL}$, hematocrite rate: $33 \%$, granulocyte: $44.5 \%$, C-reactive protein (CRP): $22 \mathrm{mg} / \mathrm{L}$, erytrocyte sedimentation rate (ESR): $60 \mathrm{~mm} / \mathrm{h}$, Epstein-Barr virus (EBV) viral capsid antigen (VCA) IgM and Cytomegalovirus (CMV) IgM were negative and there were no growth in throat, blood and urine cultures (Table 1). Because of his clinical findings which was supported the $\mathrm{KH}$ disease and fever that lasted more than five days, echocardiography was performed and polymerase chain reaction (PCR) was performed to detect some viral agents, with the purpose of finding the probable viral upper respiratory infection. The presence of hyperechogenic image in the left coronary artery with echocardiography was evaluated as compatible with coronary arteritis, which is the one of early findings of KD. Intravenous immunoglobulin (IVIG) and acetylsalicylic acid were given to the patient at $2 \mathrm{gr} /$ $\mathrm{kg}$ dosage for 1 day, and $90 \mathrm{mg} / \mathrm{kg} /$ day, respectively. In the patient's follow up process, after his fever had decreased, acetylsalicylic acid was decreased to a dosage of $5 \mathrm{mg} / \mathrm{kg} /$ day. Human adenovirus was determined by multiplex PCR. The patient was followed with echocardiography which was made at the $15^{\text {th }}$ day of therapy, and it was seen that the coronary arteritis had completely regressed and there was no aneurysms.

\section{Case 2}

A 3-years-old male child was brought to pediatrics clinic with a complaint of fever for 3 days. There was no remarkable feature in the patient's background and family history excluding his treatment with ceftriaxone for his feverish disease in the last 2 days. He was looked as pale and exhausted. Fever $\left(39^{\circ} \mathrm{C}\right)$, hyperemic and hypertrophic tonsils, strawberry tongue, painful and mobile bilateral cervical and submandibular lymphadenopathies $1 \times 2 \mathrm{~cm}$ in size were detected in his physi- cal examination. His heart rate was 128 beats/min and there was no murmur. There were not pathological signs in abdominal and respiratory system examination. Peripheral blood leukocyte count: $16.050 / \mathrm{mm}^{3}$, hemoglobin: $11.2 \mathrm{gr} / \mathrm{dl}$, \%hematocrit: $32.3 \%$, granulocyte: 75.5\%, CRP: $94 \mathrm{mg} / \mathrm{L}$, and ESR: $61 \mathrm{~mm} / \mathrm{h}$. EBV VCA IgM and CMV IgM were negative, and there were no growth in throat, blood and urine cultures (Table 1). Multiplex PCR was performed on the upper respiratory tract specimen to detect the probable viral respiratory agents. Because his fever had exceeded 4 days and nonpurulant conjunctivitis was clinically visible, echocardiography was performed with suspicion for KD. Hyperechogenic image in the left coronary artery by echocardiography was evaluated to be compatible with coronary arteritis. Therefore, the patient was evaluated as KD, and IVIG was given at $2 \mathrm{gr} / \mathrm{kg}$ dosage for the first day. In addition to that, acetylsalicylic acid was started $90 \mathrm{mg} / \mathrm{kg} /$ day. After his fever had decreased, acetylsalicylic acid was decreased to a dosage of $5 \mathrm{mg} / \mathrm{kg} /$ day. Adenovirus was detected in multiplex PCR. In the follow up period, echocardiography was repeated at the $15^{\text {th }}$ day of therapy and it was seen that the coronary arteritis completely regressed and there were no aneurysms.

\section{Discussion}

Although we do not know the incidence of KD in Turkey, and in the United States of America, it makes up for the $23 \%$ of rheumatological diseases in children and it is the second most common connective tissue disease, after Henoch-Schönlein vasculitis [3]. In addition, if left untreated, it may cause mortality and morbidity and it has no specific diagnostic test. It is more commonly seen in boys with a ratio of 1.5:1 and 2:1 [3,7,8]. In our study two of our cases were boys.

$\mathrm{KD}$ is usually seen in winter, although in some Asian countries it has a peak in summer [9]. Our two patients were admitted in winter. The seasonality of this disease may be related by infectious etiology. Genetic tenden-

Table 1: Laboratory and echocardiographical findings of cases.

\begin{tabular}{|l|l|l|}
\hline & Patient 1 & Patient 2 \\
\hline Peripheral blood leukocyte count $\left(/ \mathrm{mm}^{3}\right)$ & 5.500 & 16.050 \\
\hline Granulocyte $(\%)$ & 44.5 & 75.5 \\
\hline C-reactive protein $(\mathrm{mg} / \mathrm{L})$ & 22 & 94 \\
\hline Erytrocyte sedimentation rate (mm/hour) & 60 & 61 \\
\hline Hemoglobin (g/dL) & 11 & 11.2 \\
\hline Hematocrite rate (\%) & 33 & 32.3 \\
\hline EBV-VCA lgM & Negative & Negative \\
\hline Cytomegalovirus IgM & Negative & Negative \\
\hline Bacterial cultures (throat, urine, and blood) & Negative & Negative \\
\hline Multiplex PCR for respiratory viruses & Human adenovirus & Human adenovirus \\
\hline First echocardiography & Coronary arteritis & Normal \\
\hline Second echocardiography & Normal & arteritis \\
\hline
\end{tabular}

EBV-VCA: Epstein-Barr virus viral capsid antigen; PCR: polymerase chain reaction. 
Table 2: Symptoms and signs of KD.

At least five days of fever, which cannot be explained by any other reason

Bilateral non-exudative conjunctival congestion

Changes in oropharynx: Mucosal erythema, red and/or dry lips, a strawberry tongue

Changes in the periphery of extremities: Erythema characteristically in palms and soles, indurations in hands and feet, edema or periungual membranous desquamation

Polymorph exanthema (mainly in trunk, non-vesicular)

Acute nonsuppurative cervical adenopathy (usually unilateral, minimum $1.5 \mathrm{~cm}$ in diameter, solitary or multiple)

cies and triggering factors such as infectious agents have been regarded as possible etiologic factors for KD. Some studies found that children who have FC gamma FcyRIIA and ITPKC genes are prone to disease especially in Japanese people, and in North Americans there is a tendency for coroner artery aneurysms [10]. The ITPKC gene is described as a T-cell activity modulator [10]. Infectious agents are considered as environmental causes and that they trigger KD in people with genetic tendencies [11]. Many infectious bacterial and viral agents have been sporadically isolated from patients such as Staphylococcus aureus, Streptococcus pyogenes, atypical pathogens, Epstein-Barr virus, adenovirus, parvovirus $B 19$, Herpes Simplex virus type 6, parainfluenza type 3, measles, rotavirus, dengue virus, Varicella, 2009 H1N1 pandemic influenza and coxsackie B3 virus, and HIV. Recent studies regarding viral agents suggest that human coronavirus may have an etiological role, but this suggestion has not been validated with ongoing studies. Adenovirus was first found in the autopsy of a patient with fetal KD [12], also it was seen in the nasal swabs of 70 patients with complete or non-complete KD diagnosis by PCR [13]. In our patients with KD, adenovirus was isolated by using PCR in our patients by using PCR.

Diagnosis of KD is made by the presence of at least 5 of the following; fever, changes in the periphery of extremities, polymorphic exanthema, bilateral conjunctival non-purulant congestion, changes in oropharyngeal mucosa and cervical lymphadenopathy (Table 2). If there is a prolonged fever and involvement of coronary arteries in echocardiography, it is defined as an incomplete $K D[2,3,14]$. Most of the time differential diagnosis can be made with clinical and laboratory findings, although there are some difficulties in incomplete cases. In a study from Japan, $20 \%$ of cases did not meet the criteria for diagnosis [15]. EBV and adenovirus infections must be considered in the differential diagnosis. As we know, adenovirus may present with high fever, membranous/exudative tonsillitis, conjunctivitis, signs of gastroenteritis $[13,16]$. It may also cause leukocytosis, neutrophilia or lymphocytosis, and elevation of acute phase reactants [16]. Adenovirus, which is both an etiological agent and part of the differential diagnosis, can present itself as an incomplete KD. It is difficult to recognize and diagnose incomplete $K D$ as the greatest risk for coronary artery aneurysm which also in these patient group with incomplete KD. One of our patients was diagnosed as complete $\mathrm{KD}$, and other patient fulfills the criteria for incomplete KD with four criteria and echocardiography findings. Bear in mind that incomplete KD has the highest risk for coronary artery aneurysm. There were prolonged fever and lymphoid involvement in our patients. KD is a pediatric vasculitis, which causes a systemic inflammatory response, and if left untreated it will also involve coronary arteries. As a result of that, incomplete KD must be kept in mind as a differential diagnosis in children who are under 5 years of age, who have a high fever for 5 days, and who do not meet the criteria for complete KD and resemble a viral disease with or without exanthemas.

\section{Acknowledgements}

We would like to thank Şahap Aksaçlı and Burcu Öksüz (biologists at Yeditepe University Faculty of Medicine, Department of Medical Microbiology) for their excellent technical assistance in analyzing Human Adenovirus by PCR. We are also grateful to Hakan Şentürk (Writing Center Consultant of Yeditepe University) for the revision of this paper in English.

\section{References}

1. Kawasaki T (1967) Acute febrile mucocutaneous syndrome with lymphoid involvement with specific desquamation of the fingers and toes in children. Arerugi 16: 178-222.

2. Council on Cardiovascular Disease in the $Y$, Committee on Rheumatic Fever E, Kawasaki D, American Heart A (2001) Diagnostic guidelines for Kawasaki disease. Circulation 103: 335-336.

3. Cimaz R, Falcini F (2003) An update on Kawasaki disease. Autoimmun Rev 2: 258-263.

4. Nakamura $\mathrm{Y}$, Yashiro $\mathrm{M}$, Uehara R, Oki I, Watanabe M, et al. (2008) Epidemiologic features of Kawasaki disease in Japan: Results from the nationwide survey in 2005-2006. J Epidemiol 18: 167-172.

5. Yellen ES, Gauvreau K, Takahashi M, Burns JC, Shulman S, et al. (2010) Performance of 2004 American Heart Association recommendations for treatment of Kawasaki disease. Pediatrics 125: e234-e241.

6. Muise A, Tallett SE, Silverman ED (2003) Are children with Kawasaki disease and prolonged fever at risk for macrophage activation syndrome. Pediatrics 112: e495.

7. Kasapçopur Ö, Beker D, Çalışkan S ve ark (2000) Kawasaki sendromu. Türk Pediatri Arşivi 35: 160-163.

8. Ergüven M, Yasa O, Kral A, Bulut Ö (2010) Kawasaki Hastalığı Tanısı Almış Hastalarımızda Epidemiyolojik, Klinik, Laboratuvar, Prognostik Özelliklerinin ve Ekokardiyografik 
Bulgularının Değerlendirilmesi. Çocuk Dergisi 10: 86-89.

9. Newburger JW (2000) Kawasaki disease: Who is at risk? J Pediatr 137: 149-152.

10. Lv YW, Wang J, Sun L, Zhang JM, Cao L, et al. (2013) Understanding the pathogenesis of Kawasaki disease by network and pathway analysis. Comput Math Methods Med 2013: 989307

11. Principi N, Rigante D, Esposito S (2013) The role of infection in Kawasaki syndrome. J Infect 67: 1-10.

12. Embil JA, McFarlane ES, Murphy DM, Krause VW, Stewart HB (1985) Adenovirus type 2 isolated from a patient with fatal Kawasaki disease. Can Med Assoc J 132: 1400.

13. Jaggi $P$, Kajon AE, Mejias A, Ramilo O, Leber A (2013)
Human adenovirus infection in Kawasaki disease: a confounding bystander? Clin Infect Dis 56: 58-64.

14. Fugushige N, Takahashi N, Ueda K, Ueda Y (1994) Incidence and clinical features of incomplete Kawasaki Disease. Acta Paediatr 83: 1057-1060.

15. Nakamura $Y$, Yashiro M, Uehara R, Sadakane A, Chihara I, et al. (2010) Epidemiologic features of Kawasaki disease in Japan: Results of the 2007-2008 nationwide survey. J Epidemiol 20: 302-307.

16. Biçer S, Küçük O, Giray T, Cöl D, Ciler Erdağ, et al. (2013) Evaluation of clinical and laboratory findings of pediatric patients with adenovirus-associated respiratory tract infections. Mikrobiyol Bul 47: 295-304. 